\title{
Improving the Ability of Representation and Problem Solving Through Concrete Representational Abstract (CRA) Approach in Mathematical Learning
}

\author{
Zulfakri1,a, ${ }^{*}$ M. Ikhsan ${ }^{1, b}$, and Yusrizal1,c \\ ${ }^{1}$ Master of Mathematics Education, Syiah Kuala University, Jl. Teungku Chik Pante Kulu No. 5 Banda Aceh 23111,Indonesia \\ a zulfakri.co@gmail.com; b Ikhsan@unsyiah.ac.id; c yusrizal_fkip@unsyiah.ac.id \\ ${ }^{*}$ Corresponding Author \\ Whatsapp number [+62-853 73436066$]$
}

How to Cite: Zulfakri, Z. Ikhsan, M.,Yusrizal, Y. (2019). Improving the Ability of Representation and Problem Solving Through Concrete Representational Abstract (CRA) Approach in Mathematical Learning. International Journal for Educational and Vocational Studies, 1 (3), 244-248.

\section{ARTICLE HISTORY}

Received: 12 June 2019

Revised: 27 June2019

Accepted: 16 July 2019

\section{KEYWORDS}

Mathematical Representation Ability,

Problem Solving Ability,

Concrete Representational

Abstract (CRA) Approach

\section{ABSTRACT}

The representation and mathematical problem-solving abilities of students are still relatively low. The low ability is due to the lack of attention of the implementers of learning to develop learning that can improve the ability of representation and mathematical problem-solving. One effort that can be done is to apply to learn through the Concrete Representational Abstract (CRA) approach. This study aims to analyze the increase in representation ability and mathematical problem solving of students and to examine the interaction between student learning and the ability of representation and mathematical problem solving of students. This research is quantitative research with an experimental method with the design of the pretest-posttest group design. The population of this study was all students of SMP Negeri 1 Banda Aceh with a sample of two classes which became the experimental and control classes. The instrument of data collection is a test of representation ability and mathematical problem-solving. Data analysis of the study was carried out with SPSS 23 assisted two-way ANOVA for windows at a significant level of 0.05 . The results of the study showed that: 1 ) the improvement of the representation and mathematical problem-solving abilities of students who obtained learning through the CRA approach was better than improving the problem-solving abilities of students who obtained conventional learning 2) there was no interaction between the CRA approach and the student level towards improving representation and solving abilities mathematical problem.

This is an open access article under the CC-BY-SA license.

\section{INTRODUCTION}

The core competencies in mathematics learning that are mandated by the 2013 curriculum are a reference for learning in schools. The core competencies formulated by the Ministry of Education and Culture (2003: 45) are the ability to try, process, and present in concrete realms (using, parsing, modifying, and making) and abstract domains (writing, reading, counting, drawing, and composing) ) in accordance with what is learned in school and other similar sources in the perspective / theory. In Learning Mathematics, the core competency is a manifestation of mathematical power development (Mathematical Power). According to Pinellas County Schools (2000) mathematical power includes (1) Standard Process , namely the goals to be achieved from the learn- ing process of mathematics in schools that include problem solving skills, ability to argue, the ability to communicate, the ability to make connections, and the ability of representation; (2) The scope of the material, namely the basic competencies contained in the curriculum according to the level of student learning, for Indonesia the scope of mathematics subjects in educational units; (3) Mathematical abilities, namely the knowledge and basic skills needed to manipulate mathematics include understanding concepts and procedural knowledge.

NCTM (2000) also said that learning mathematics also requires students to have understanding skills, problemsolving, communication, mathematical connections and 
representations of ideas. These six abilities are important abilities developed in schools at every level. According to Nurhasanah (2010: 1), mathematics with abstract studies can be taught by utilizing concrete objects (concrete) so that mathematics learning is easy for students to learn. To be able to achieve abstract abilities, mathematics learning in schools should be directed at developing mathematical abilities. Among the mathematical abilities, students need to achieve the above goals are the ability of representation and problem-solving.

Hwang et al. (2007: 197) define mathematical representation as to the process of modeling something concrete from the real world into abstract concepts or symbols. Furthermore, NCTM (2000: 67) explains that representations that are generated by students are expressions of mathematical ideas or ideas displayed by students in their efforts to find a problem they are facing.

Jones (2000) explains the importance of representation as one of the process standards, namely (1) Fluency in translating between various forms of representation that is diverse is the basic ability that students need to have to develop a concept and think mathematically, (2) How the teacher presents ideas -ide mathematics through various representations will have a very large influence on students' understanding of learning mathematics, (3) Students need practice in building their own representation so that they have the ability and understanding of strong and flexible concepts that can be used in solving problems.

Furthermore Hudiono (2005: 25) states that representation has several goals that must be achieved by students, namely: (1) Creating and using representations to recognize, record and communicate mathematical ideas (2) Select, apply and translate mathematical representations to solve problem (3) Using mathematical representations to model and interpret physical, social or mathematical phenomena. Given the importance of the ability of mathematical representation that students must have, mathematical learning must be able to develop the ability of representation. But in its implementation at school, this is not easy.

According to Saepuloh (2013: 3), the limitations of teacher knowledge and the habits of students learning in a conventional way have not made it possible to develop representation capabilities optimally. Broadly speaking, representation capabilities at both the elementary and secondary levels have not been handled properly. This is indicated by the still low number of students who can solve non-routine questions such as Olympic questions that emphasize students to be able to translate abstract knowledge into concrete or vice versa.

Some studies suggest that the ability of mathematical representation is less developed in learning. Hutagaol's research (2007) states that students lack representation capacity because students are never given the opportunity to do their own representation, students are required to follow what the teacher has exemplified. This causes students not to be able to present mathematical ideas properly. Then Amri (2009) added that in mathematics learning with regard to representation still using conventional methods so students tend to follow the teacher's steps, students are never given the opportunity to present their representations.

In addition to representation, problem-solving abilities are also important to be developed in mathematics learning. The importance of solving mathematical problems is confirmed by NCTM (2000: 52) which explains that problem-solving is an integral part of mathematics learning, so that it cannot be eliminated from mathematics learning. In addition, problem-solving abilities are the goal of mathematics learning. Furthermore, NCTM establishes problemsolving as an objective and approach. Solving the problem is interpreted with answer a question where the method for finding a solution to the question is unknown first. To find a solution, students must use things that have been learned before and through a process where they will develop new mathematical understandings. Solving problems is not just a goal of learning mathematics but is also the main tool for carrying out mathematics learning.

NCTM strongly suggests incorporating problem-solving in school mathematics. Tabrani (2008: 5) reveals the reasons for the importance of problem-solving, namely (1) problem solving allows connecting learning with everyday life, because the problems raised in ordinary learning activities are taken from everyday life, or from what they experience. (2) Problem-solving can stimulate the intellectual abilities and thinking the power of students because in thinking using problem solving they highlight problems in various ways. (3) Problem-solving can train and familiarize students to deal with and solve problems carefully. (4) Problem-solving is able to train students to think systematically and relate it to other problems.

According to Wardhani and Rumiati (2011) in general, the weakness of our students is that they have not been able to develop reasoned abilities, do not have the habit of reading while thinking and working in order to understand the essential and strategic information in solving problems, and still tend to receive information and then forget it. So that mathematics learning has not been meaningful.

The initial study that the author did at SMP Negeri 1 Banda Aceh, by giving a test question in the form of two items that included each ability to solve problems and representations. In this initial study, the authors found that more than $70 \%$ of students have low problem solving and representation skills. Based on the results of interviewing the writer with one of the teachers of SMP Negeri 1 Banda Aceh, who said that students were still difficult in completing non-routine questions. When students are faced with non-routine questions that compel them to think more, students are not able to translate 
mathematical expressions into life or vice versa. Students also cannot express arguments regarding problems faced with them. The completion of these non-routine questions requires adequate mathematical abilities, including representation and problem-solving abilities. This situation is caused by the lack of implementation of learning that allows students to develop these abilities. Learning that takes place is still one-way and the teacher is the only source of knowledge information. For this reason, it is necessary to develop appropriate learning along with the development of students' mathematical abilities such as representation and problem-solving.

The above issues should be considered and resolved together by all elements of education, both teachers in schools and other mathematicians. One effort that can be done by the teacher is to teach mathematics with the right model or approach along with the development of students' mathematical abilities such as representation and problem-solving. One of the innovations to study existing mathematics learning is to use the CRA ( Concrete Representational Abstract) approach.

The CRA approach can also help students understand mathematical concepts and be carried out in stages according to students' abilities. The CRA (Concrete Representational Abstract) approach was first used by Mercer and Miller. They used the CRA approach to teach the basic concepts of addition, subtraction, multiplication, and division in children who have difficulty learning mathematics. Kathlyn Steedly et al (2008: 8) explain that the CRA approach is an instruction in mathematics learning that combines visual representation. CRA is an approach that has three instructional parts that allow the teacher to use Concrete(such as hip color, geometric numbers, block patterns, or camps and direct activities carried out by students) to model mathematical concepts that must be studied, then show concepts through Representational (such as drawing shapes) and the last is Abstract or symbolic (such as numbers, notations, or other mathematical symbols).

The CRA approach also has the advantages mentioned by NCTM (2000) that the CRA approach lies in intensity and concreteness that helps students maintain a framework in their working memory to solve problems. As research conducted by Yuliawaty (2011: 118) which mentions that mathematics learning through the CRA ( Concrete Representational Abstract ) approach is able to improve students 'mathematical abilities, in their study it was stated that improvement of students' mathematical problem-solving skills obtained learning using the CRA ( Concrete Representational)approach Abstract) better than students who get conventional learning. Whereas the research conducted by Rahmawati (2013: 40) states that an increase in mathematical problem-solving abilities of students who obtain learning using the CRA ( Concrete Representational Abstract) approach is no better than students who use expository learning.
The formulation of the problem in this paper is whether the increase in the ability to respond and solve mathematical problems of students taught by the CRA ( Concrete Representational Abstract) learning approach is better than increasing the problem-solving abilities taught conventionally. And whether there is an interaction between the CRA ( Concrete Representational Abstract ) learning approach factor and the student level towards improving students' representation and mathematical problem-solving abilities.

\section{METHODS}

This research is an experimental study with a group design pretest-posttest control group design. This study uses two classes namely the experimental class and the control class. The experimental class is given treatment ( treatment) learning using the Concrete Representational Abstract approach(CRA) which aims to see symptoms or changes in students related to the ability of problem-solving and mathematical representation.

Next, to see symptoms or changes in treated subjects, the need for a comparison subject group called the control class. The population and sample in this study were seventh-grade students of SMP Negeri 1 Banda Aceh with a sample of 2 classes consisting of 31 students with similar abilities. The homogeneity is proven by testing the pretest scores of the two classes which obtain the t count of 0.720 with the sig value. (2-tailed) the pretest score was 0.474 greater than $a=0.05$ in the ability of mathematical representation and 0,280 with the sig value. (2-tailed) the pretest score was 0.780 greater than $\alpha=0.05$ in problem-solving abilities.

Based on the results obtained, it shows that there is no significant difference between the pretest of the experimental class and the control class on the ability of mathematical representation and problem solving so that it can be concluded that both classes have the same initial ability. The research instrument used was a test sheet for representation ability and mathematical problemsolving. Data obtained through pretest and posttest were calculated $\mathrm{N}$-gain then analyzed quantitatively using Anava. Before carrying out the Anava test, a normality and homogeneity test for $\mathrm{N}$-gain data was carried out. The research instrument used was a test sheet for representation ability and mathematical problemsolving. Data obtained through pretest and posttest were calculated $\mathrm{N}$-gain then analyzed quantitatively using Anava. Before carrying out the Anava test, a normality and homogeneity test for $\mathrm{N}$-gain data was carried out. The research instrument used was a test sheet for representation ability and mathematical problemsolving. Data obtained through pretest and posttest were calculated $\mathrm{N}$-gain then analyzed quantitatively using Anava. Before carrying out the Anava test, a normality and homogeneity test for $\mathrm{N}$-gain data was carried out. 


\section{RESULTS AND DISCUSSION}

To answer the objectives of the above research, analysis and interpretation of research data are needed. The data analyzed is the data of representation ability and mathematical problem solving, data to increase representation ability and problem-solving after learning using the CRA (Concrete Representational Abstract ) approach. Increasing the ability of representation and problem solving is analyzed by calculating the gain index. The gain index value was obtained from the results of the pretest and posttest of students in the control and experimental classes. This gain index will be tested to see the difference in averages. Before testing the average difference, the gain index value is tested for normality and homogeneity first.

The results of normality testing on the ability of mathematical representation obtained sig. the control class is 0.200 and the experimental class is 0.157 greater than $a=0.05$ which means the normalized gain data (N-Gain) for representation ability is normally distributed. Then testing the problem-solving abilities obtained sig. the control class is 0.157 and the experimental class 0.069 is greater than $\alpha=0,05$, which means normalized gain data (N-Gain) for representation capability is normally distributed. Homogeneity testing on mathematical representation ability obtained values of $\mathrm{F}$ $=2.214$ and $\operatorname{sig} 0.142>0.05$, it can be concluded that the gain variance normalized the ability of the mathematical representation of both homogeneous classes. Furthermore, homogeneity testing on problem-solving abilities obtained $\mathrm{F}=0.442$ and $\operatorname{sig} 0.518>0.05$, it can be concluded that the variance gain normalized the problem-solving abilities of both homogeneous classes.

Furthermore, the test of differences in the average $\mathrm{N}$-Gain of the ability of representation and mathematical problem solving of students in both classes aims to prove four hypotheses. The first hypothesis in this study relates to differences in the improvement of students' mathematical representation abilities taught by learning through the CRA ( Concrete Representational Abstract) and conventional learning approaches. The results of the study show that the improvement of students' mathematical representation skills is taught through the CRA (Concrete Representational Abstract) approach better than the ability of mathematical representation of students who are taught conventionally. This is evidenced by the results of the N-Gain test of mathematical representation capabilities with $\mathrm{t}=4,626$ and Sig. $(2$-tailed) $=0,000$. Because of doing a one-sided (1-tailed) hypothesis test, the sig (2-tailed) value must be divided into Sig. (1-tailed) $=0.0000$. Because of the value of Sig. (1-tailed) <significance level $(\alpha=0.05)$, then Ho is rejected. So it can be concluded that the normalized gain average of the experimental class's mathematical representation ability is better than the normalized gain class of the control class. This is similar to that explained by Kathlyn Steedly et al (2008:
The second hypothesis relates to differences in the improvement of students' problem-solving abilities taught by learning through the CRA ( Concrete Representational Abstract) approach and conventional learning. The results of the study indicate that the improvement of students' problem-solving abilities is taught through the CRA (Concrete Representational Abstract) approach

better than the ability of mathematical representation of students who are taught conventionally. This can be seen in the N-Gain problem-solving ability with the values $\mathrm{t}=$ 4.184 and Sig. (2-tailed) $=0,000$. Because of doing a one-sided (1-tailed) hypothesis test, the sig (2-tailed) value must be divided into Sig. (1-tailed) $=0.0000$. Because of the value of Sig. (1-tailed) <significance level $(\alpha=0.05)$, then Ho is rejected. So that it can be concluded that the normalized gain average problem-solving ability of the experimental class is better than the normalized gain average of the control class. The results of this study are in accordance with the research conducted by Yuliawaty (2011: 228) with conclusions stating that the improvement of problem-solving abilities of students who obtain learning with the CRA approach better than students who get conventional learning.

Furthermore, it is necessary to analyze the interaction between the learning approach with the student level towards improving representation and problem-solving abilities. This analysis aims to determine the effect of giving treatment to both the experimental and control classes which became the sample of the study on the improvement of students' representation and mathematical problem-solving abilities. The third hypothesis in this study relates to the interaction between learning factors with student level to increase the ability of mathematical representation. The test results obtained the value $\mathrm{F}=0.507$ with the value of sig. 0.605 greater than $\alpha=0.05$ so that it can be concluded that there is no interaction between the learning approach and the level of students towards increasing the ability of mathematical representation. (Concrete Representational Abstract) does not differ in the increase in each level of students.

Furthermore, the fourth hypothesis with regard to the interaction between learning factors with the level of students towards improving problem-solving skills. The test results obtained a value of $\mathrm{F}=0.290$ with a sig value. 0.749 is greater than $\alpha=0.05$ so it can be concluded that there is no interaction between the learning approach with the student level on improving problem-solving skills. This is due to an increase in students' problemsolving abilities through the CRA (Concrete Representational Abstract) approach that does not differ at each student's level of improvement.

\section{CONCLUSION}

Based on the results of data analysis and discussion, some conclusions were obtained, namely an increase in the ability of mathematical representation and problemsolving of students who obtained learning through the 
CRA approach, better than increasing the ability of mathematical representation to obtain conventional learning. in addition, there is no interaction between the CRA approach and the student level towards improving students' mathematical problem-solving representation abilities.

As for some suggestions that can be given is expected that mathematics learning with the CRA approach can be used as an alternative learning approach in an effort to improve mathematical presentation skills and problem-solving, especially at the junior high school level. The implementation of learning through the CRA approach also requires teachers to manage the class as well as possible and pay close attention to learning activities in order to see students' abilities during learning.

\section{REFERENCES}

Amri. (2009). Peningkatan Kemampuan Representasi Matematik Siswa SMP melalui Pembelajaran dengan Pendekatan Induktif-Deduktif. Tesis SPs UPI Bandung.

Hudiono, Bambang. (2005). Peran Pembelajaran Diskursus Multi Representasi Terhadap Pengembangan Kemampuan Matematik dan Daya Representasi pada Siswa SLTP. Bandung : Disertasi UPI

Hutagaol, K (2007) Pembelajaran Matematika Kontekstual untuk Meningkatkan Kemampuan Representasi Matematis Siswa Sekolah Menengah Pertama. Tesis SPs UPI Bandung.

Hwang, W.-Y., Chen, N.-S., Dung, J.-J., and Yang, Y.-L. (2007). Multiple Representation Skills and Creativity Effects on Mathematical Problem Solving using a Multimedia Whiteboard System. Educational Technology \& Society.

Jones, A.D. (2000). The Fifth Process Standard : An Argument to Include Representation In Standard 2000. [online] Available: htttp://www.math.umd.edu/ dac/650/jonespaper.htm 1. [3 Januari 2018]

Kemendikbud. (2013). Kurikulum 2013 Kompetensi Dasar SMP/ MTs. Jakarta : Kemendikbud

National Council of Teachers of Mathematics (NCTM). (2000). Principles and Standards for School Mathematics. United States.

Pinellas County Schoolls. (2000). Division of Curriculum And Instruction Secondary Mathematics. [online] Tersediahttp://fcit.usf.edu/fcat8m/resource/mathpowr/ fullpower.pdf

Nurhasanah, Farida. (2010). Abstraksi Siswa SMP dalam Belajar Geometri Melalui Penerapan Model Van Hiele dan Geometers Sketchpad. Tesis. Jurusan
Pendidikan Matematika UPI Bandung.

Rahmawati, Ade. (2013). Penerapan Pembelajaran Matematika Melalui Pendekatan CRA (ConcreteRepresentational-Abstract) Untuk Meningkatkan Kemampuan Pemecahan Masalah Matematis Siswa SMP. Skripsi. Jurusan Pendidikan Matematika UPI Bandung.

Saepuloh, Asep Rahmat. (2013). Penerapan Model Pembelajaran Sinetik Untuk Meningkatkan Kemampuan Representasi dan Komunikasi Matematis Siswa SMP. Tesis. Jurusan Pendidikan Matematika UPI Bandung.

Steedly Kathlyn, dkk. (2008). Effective Mathematics Instruction. NICHCY.

Tabrani, Rusyan. (2008). Cara pembelajaran matematika seri I. Semarang:PT Bengawan Ilmu.

Yuliawaty, Lia. (2011). Pembelajaran Matematika dengan Pendekatan CRA (Concrete Representational Abstract) untuk Meningkatkan Kemampuan Pemahaman dan Pemecahan Masalah Matematik Siswa SMP. Tesis. Jurusan Pendidikan Matematika UPI Bandung.

Wardhani dan Rumiati (2011). Instrumen Penilaian Hasil Belajar Matematika SMP : Belajar dari PISA dan TIMSS. Yogyakarta: PPPPTK Matematika. 